\title{
A grand challenge in evolutionary and population genetics: new paradigms for exploring the past and charting the future in the post-genomic era
}

\author{
Joshua M. Akey ${ }^{*}$ and Mark D. Shriver ${ }^{2 *}$ \\ Department of Genome Sciences, University of Washington, Seattle, WA, USA \\ 2 Department of Anthropology, Pennsylvania State University, University Park, PA, USA \\ *Correspondence: akeyj@u.washington.edu; mds17@psu.edu
}

New doors to a deeper understanding of the evolutionary and population genetics of life have been opened through recent technological, informational, and computational advances. Over the past decade we have seen molecular biology and computational capacities increase by several orders of magnitude. In some important ways the science and study of evolutionary genetics today is between paradigms. Like some 100 years ago after the rediscovery and confirmation of Mendel's genetics, but before the emergence of population genetics and the modern synthesis, today we are working in the immediate post-genomic time, finding ourselves on the precipice of a mature or synthetic understanding of evolutionary genetics and genomics. Molecular and other technologies are being developed at an everincreasing rate, and it is hard to keep abreast of all the new methods. Likewise, databases and statistical methods are advancing and growing rapidly.

Approaches to evolutionary studies such as ancient DNA and single-cell molecular biology, which once held promise but had fallen by the wayside due to technical limitations, are being revitalized and are changing the way we think about what can be studied. For example, although genomewide association studies (GWAS) have not led to the identification of many genes of large effect, it has helped facilitate personalized disease-risk estimation through new methods focused on combining the smaller effects from many independent loci. These methods facilitate trait value prediction and represent a powerful tool for identifying novel pathways of disease and phenotypic variation (de los Campos et al., 2010). Evolutionary and population geneticists also benefit from a growing understanding of the functional, phenotypic, and medical effects of genetic variation. GWAS on disease and non-disease traits, burgeoning functional genomics technologies such as ChiP-SEQ and RNA-SEQ, and systematic catalogs of gene deletions in a variety of model organisms are examples of projects that can and should inform the study of evolutionary genetics broadly.

The future of evolutionary and population genetics is simultaneously exciting and daunting. It is exciting because we are in the early stages of having massively large and powerful data sets to address fundamental questions about the forces that shape patterns of genetic variation within and between species. It is daunting because the methodological tools and theoretical models needed to interpret these data sets are still in their infancy. In the following, we articulate some of the most pressing challenges confronting evolutionary and population genetics.

An obvious challenge is the analysis and interpretation of (the current) nextgeneration sequencing technologies, which have democratized whole-genome sequencing. At long last, individual laboratories can accomplish projects that were once the sole purview of large-scale sequencing centers (Shendure and Hanlee, 2008).Wholegenome sequence data are now available for hundreds of species and are being generated in thousands of individuals from particular populations. Whole-genome sequence data can open new windows on the evolutionary process, such as descriptions of sex-biased dispersal and mutation rate biases (e.g., Wilson Sayres et al., 2011). Not even extinction is a guarantee against having one's genome sequenced or one's mating habits analyzed (e.g., Green et al., 2010; Reich et al., 2010). Nor is extinction necessarily a guarantee against being resurrected. Moreover, the hope that such sequencing projects might help forest all the extinction of endangered species also shines bright (e.g., Miller et al., 2011).
Although genome-wide scans for positive selection have now become routine in many organisms (Akey, 2009), these studies have yielded little information into the precise mechanistic basis of how natural and domesticated populations evolve. Indeed, a recent study suggests that selection acting on newly arisen advantageous mutations has been surprisingly rare in recent human evolutionary history (Hernandez et al., 2011). If selection in humans does not abide by this classic model of adaptive evolution, then what selective models are consistent with the data? Previous candidate gene analyses provide a glimpse into the types of complexity that await more detailed analyses, such as selection from standing variation (Enattah et al., 2008; Magalon et al., 2008; Scheinfeldt et al., 2009), evidence for both directional and balancing selection acting on the same locus (Tishkoff et al., 2001; Verrelli et al., 2002), and epistatic selection (Williams et al., 2005). Additionally, with the advent of growing databases of sex hormone enhancer elements perhaps we are finally poised to approach the role of sexual selection on the genomic level (e.g., McLean et al., 2011). Thus, an ongoing major challenge in evolutionary and population genetics is to delineate more precisely the tempo and mode of adaptive evolution and to study the similarities and differences in adaptive trajectories between species and how these are influenced by population demographic history.

More fundamentally, new insights about basic biological mechanisms have provoked calls that the modern synthesis needs to be expanded (e.g., Kutschera and Niklas, 2004; Pigliucci, 2007 and references therein). For instance, how does the evolution of evolvability, epigenetic inheritance, phenotypic plasticity, and the origins of complexity (reviewed in Pigliucci, 2007) fit, if at all, into the modern synthesis? Although the relevance of these ideas to the need for an 
expanded modern synthesis is controversial (Pennisi, 2008), they should not be categorically dismissed. Rather, such ideas should be subjected to rigorous and systematic study, and their contribution to evolutionary processes and relationships with currently held evolutionary paradigms should be investigated on a case-by-case basis.

Fulfilling the promise of evolutionary and population genetics will require approaches that increasingly leverage and apply knowledge gleaned across disciplines in novel, creative, and ultimately insightful ways. Likewise, evolutionary genetic approaches can and should contribute to our general understanding of the life sciences from anatomy to zoology. Finally, over the next few years, as the genealogical genetics, nutragenomics, and personalized disease-risk genotyping industries expand into a more mature era of personal genomics, evolutionary, and population geneticists can and should help facilitate an informed interpretation of these data. Failing to do so, preferring "pure science" to public engagement will be to our collective loss. Our goal is for Frontiers in Evolutionary and Population Genetics to be an interdisciplinary forum for addressing these issues and more.

\section{REFERENCES}

Akey, J. M. (2009). Constructing genomic maps of positive selection in humans: where do we go from here? Genome Res. 19, 711-722.

de los Campos, G., Gianola, D., and Allison, D. B. (2010). Predicting genetic predisposition in humans: the promise of whole-genome markers. Nat. Rev. Genet. $11,880-886$

Enattah, N. S., Jensen, T. G., Nielsen, M., Lewinski, R., Kuokkanen, M., Rasinpera, H., El-Shanti, H., Seo, J. K., Alifrangis, M., Khalil, I. F, Natah, A., Ali, A., Natah, S., Comas, D., Mehdi, S. Q., Groop, L., Vestergaard, E. M., Imtiaz, F., Rashed, M. S., Meyer, B., Troelsen, J., and Peltonen, L. (2008). Independent introduction of two lactase-persistence alleles into human populations reflects different history of adaptation to milk culture. Am. J. Hum. Genet. 82, 57-72.
Green, R. E, Krause, J., Briggs, A. W., Maricic, T., Stenzel, U., Kircher, M., Patterson, N., Li, H., Zhai, W., Fritz, M. H., Hansen, N. F., Durand, E. Y., Malaspinas, A. S. Jensen, J. D., Marques-Bonet, T., Alkan, C., Prüfer, K., Meyer, M., Burbano, H. A., Good, J. M., Schultz, R., Aximu-Petri, A., Butthof, A., Höber, B., Höffner, B., Siegemund, M., Weihmann, A., Nusbaum, C., Lander, E. S., Russ, C., Novod, N., Affourtit, J., Egholm, M. Verna, C., Rudan, P., Brajkovic, D., Kucan, Z., Gusic, I., Doronichev, V. B., Golovanova, L. V., Lalueza-Fox, C., de la Rasilla, M., Fortea, J., Rosas, A., Schmitz, R. W., Johnson, P. L., Eichler, E. E., Falush, D., Birney, E., Mullikin, J. C., Slatkin, M., Nielsen, R., Kelso, J., Lachmann, M., Reich, D., and Pääbo, S. (2010). A draft sequence of the Neandertal genome. Science $328,710-722$

Hernandez, R. D., Kelley, J. L., Elyashiv, E., Melton, S. C., Auton, A., McVean, G., 1000 Genomes Project, Sella, G., and Przeworski, M. (2011). Classic selective sweeps were rare in recent human evolution. Science 331, 920-924.

Kutschera, U., and Niklas, K. J. (2004). The modern theory of biological evolution: an expanded synthesis. Naturwissenschaften 91, 255-276.

Magalon, H., Patin, E., Austerlitz, F., Hegay, T., Aldashev,A. Quintana-Murci, L., and Heyer, E. (2008). Population genetic diversity of the NAT2 gene supports a role of acetylation in human adaptation to farming in Central Asia. Eur. J. Hum. Genet. 16, 243-251.

McLean, C. Y., Reno, P. L., Pollen, A. A., Bassan, A. I. Capellini, T. D., Guenther, C., Indjeian, V. B., Lim, X., Menke, D. B., Schaar, B. T., Wenger, A. M., Bejerano, G., and Kingsley, D.M.(2011). Human-specific loss of regulatory DNA and the evolution of human-specific traits. Nature 471, 216-219.

Miller, W., Hayes, V. M., Ratan, A., Petersen, D. C., Wittekindt, N. E., Miller, J., Walenz, B., Knight, J., Qi, J., Zhao, F., Wang, Q., Bedoya-Reina, O. C., Katiyar, N., Tomsho, L. P., McClellan Kasson, L., Hardie, R. A., Woodbridge, P., Tindall, E. A., Bertelsen, M. F., Dixon, D., Pyecroft, S., Helgen, K. M., Lesk, A. M., Pringle, T. H., Patterson, N., Zhang, Y., Kreiss, A., Woods, G. M., Jones, M.E., and Schuster, S.C. (2011). Genetic diversity and population structure of the endangered marsupial Sarcophilus harrisii (Tasmanian devil). Proc. Natl. Acad. Sci. U.S.A. PMID: 21709235. [Epub ahead of print].

Pennisi, E. (2008). Evolution. Modernizing the modern synthesis. Science 321, 196-197.

Pigliucci, M. (2007). Do we need an extended evolutionary synthesis? Evolution 61, 2743-2749.

Reich, D., Green, R. E., Kircher, M., Krause, J., Patterson, N., Durand, E. Y., Viola, B., Briggs, A. W., Stenzel, U., Johnson, P. L., Maricic, T., Good, J. M., MarquesBonet, T., Alkan, C., Fu, Q., Mallick, S., Li, H., Meyer,
M., Eichler, E. E., Stoneking, M., Richards, M., Talamo, S., Shunkov, M. V., Derevianko, A. P., Hublin, J. J., Kelso, J., Slatkin, M., and Pääbo, S. (2010). Genetic history of an archaic hominin group from Denisova Cave in Siberia. Nature 468, 1053-1060.

Scheinfeldt, L. B., Biswas, S., Madeoy, J., Connelly, C. F., Schadt, E. E., and Akey, J. M. (2009). Population genomics analysis of ALMS1 in humans reveals a surprisingly complex evolutionary history. Mol. Biol. Evol. 26, 1357-1367.

Shendure, J., and Hanlee, J. (2008). Next-generation DNA sequencing. Nat. Biotechnol. 26, 1135-1145.

Tishkoff, S. A., Varkonyi, R., Cahinhinan, N., Abbes, S., Argyropoulos, G., Destro-Bisol, G., Drousiotou, A., Dangerfield, B., Lefranc, G., Loiselet, J., Piro, A., Stoneking, M., Tagarelli, A., Tagarelli, G., Touma, E. H., Williams, S. M., and Clark, A. G. (2001). Haplotype diversity and linkage disequilibrium at human G6PD: recent origin of alleles that confer malarial resistance. Science 293, 455-462.

Verrelli, B. C., McDonald, J.H., Argyropoulos, G., DestroBisol, G., Froment, A., Drousiotou, A., Lefranc, G., Helal, A. N., Loiselet, J., and Tishkoff, S. A. (2002). Evidence for balancing selection from nucleotide sequence analyses of human G6PD. Am. J. Hum. Genet. 71, 1112-1128.

Williams, T. N., Mwangi, T. W., Wambua, S., Peto, T. E., Weatherall, D. J., Gupta, S., Recker, M., Penman, B. S., Uyoga, S., Macharia, A., Mwacharo, J. K., Snow, R. W., and Marsh, K. (2005). Negative epistasis between the malaria-protective effects of alpha+-thalassemia and the sickle cell trait. Nat. Genet. 37, 1253-1257.

Wilson Sayres, M. A., Venditti, C., Pagel, M., and Makova, K. D. (2011). Do variations in substitution rates and male mutation bias correlate with life history traits? A study of 32 mammalian genomes. Evolution. doi: 10.1111/j.1558-5646.2011.01337.x. [Epub ahead of print].

Received: 25 June 2011; accepted: 04 July 2011; published online: 21 July 2011.

Citation: Akey JM and Shriver MD (2011) A grand challenge in evolutionary and population genetics: new paradigms for exploring the past and charting the future in the post-genomic era. Front. Gene. 2:47. doi: 10.3389/ fgene.2011.00047

This article was submitted to Frontiers in Evolutionary and Population Genetics, a specialty of Frontiers in Genetics. Copyright ( 12011 Akey and Shriver. This is an open-access article subject to a non-exclusive license between the authors and Frontiers Media SA, which permits use, distribution and reproduction in other forums, provided the original authors and source are credited and other Frontiers conditions are complied with. 